\title{
Anticipating and Addressing Stakeholders' Stereotypes of Evaluation
}

\author{
John LaVelle \\ University of Minnesota
}

\begin{abstract}
It is likely that program and policy stakeholders hold biases and stereotypes about both evaluators and evaluation. Evaluators can challenge stakeholders' negative stereotypes through communication strategies and intentional word choice, but first they must recognize the existence of stakeholders' stereotypes. This Practice Note describes an instructional activity designed to help evaluators and participants in evaluator education experiences hone their communication skills, with a focus on describing evaluative perspectives, processes, and tools in a way that is accessible to stakeholders. The process helps evaluators both to be better aware of the stereotypes and biases that stakeholders are likely to possess and to provide language to help challenge negative and/or inappropriate perceptions. The Practice Note also provides a list of common biases about evaluation, and language to help evaluators anticipate and address them.
\end{abstract}

Keywords: attitudes toward evaluation, communication, evaluation, evaluator education, stereotypes of evaluation, teaching evaluation

Résumé : Il est probable que certaines parties prenantes soient biaisées ou aient des préjugés à l'égard des évaluateurs et évaluatrices et de l'évaluation. Les évaluateurs et évaluatrices peuvent combattre les stéréotypes négatifs des parties prenantes en mettant en cuvre des stratégies de communication et en utilisant une terminologie particulière, mais doivent tout d'abord reconnaître l'existence de ces stéréotypes. La présente note sur la pratique décrit une activité pédagogique conçue pour aider les évaluateurs et évaluatrices à améliorer leurs aptitudes en communication, dans l'optique de décrire les perspectives, les processus et les outils d'évaluation d'une façon accessible aux parties prenantes. Le processus aide les évaluateurs et évaluatrices à mieux connaître les stéréotypes et les biais probables des parties prenantes, ainsi qu’à offrir une terminologie qui aidera à combattre les perceptions négatives et/ou inappropriées. La note sur la pratique présente aussi une liste des préjugés communs à l'égard de l'évaluation et des termes qui aident les évaluateurs et évaluatrices à les prévoir et à les confronter.

Mots clés : attitudes à l'égard de lévaluation, communication, évaluation, formation des évaluateurs et évaluatrices, stéréotypes d’évaluation, enseignement de l’évaluation

Corresponding author: John LaVelle, Department of Organizational Leadership, Policy, and Development, College of Education and Human Development, University of Minnesota, 323 Burton Hall, 178 Pillsbury Drive, SE, Minneapolis, MN 55455; jlavelle@umn.edu

C 2020 Canadian Journal of Program Evaluation / La Revue canadienne d'évaluation de programme 35.2 (Fall / Automne), 230-239 doi: 10.3138/cjpe.61723 
Anyone entering into an evaluative relationship brings with them perspectives, biases, and stereotypes about evaluation (Donaldson, Gooler, \& Scriven, 2002). Stakeholder stereotypes about evaluation can be positive or negative; they might have been learned through direct or indirect experience, and they can be rooted in a realistic or exaggerated memory of the experience (Lane \& Crane, 2002). It is important for evaluators to be familiar with the kinds of stereotypes and biases that stakeholders hold about evaluation, as these can influence evaluative relationships, processes, and products. That is, when stakeholder biases about evaluation are negative, evaluators may encounter conflict, as well as stakeholder withdrawal, resistance, shame, anger, or more (Donaldson et al., 2002). This Practice Note describes an instructional activity designed to help evaluators and participants in evaluator education experiences hone their communication skills, with a focus on describing evaluative perspectives, processes, and tools in a way that is accessible to stakeholders.

The Encyclopedia of Evaluation describes bias as a "preference or prejudgment ... that is considered synonymous with subjective, unfair, partial, or prejudiced and is defined as errors based on beliefs or emotions that are wrong or irrelevant and that may adversely affect people and programs" (Mathison, 2005b, p. 33). Stereotypes, by contrast, are an oversimplification of the characteristics of a group of people that all members of a group are assumed to possess (Triandis, 1995). Both stereotypes and biases are attitudes, described by Mathison (2005a, p. 23) as

A predisposition to classify objects, people, ideas, and events and to react to them with some degree of evaluative consistency ... inherent in attitudes are judgements about goodness or rightness ... they are manifest in conscious behavior of an inner state, in speech, in behavior, and in physiological symptoms.

Although some stakeholders have a positive bias toward evaluation, others possess a negative bias against it, especially if they perceive evaluation as risky or potentially threatening (Scott, 2000). Working with stakeholders who hold negative attitudes about evaluation can be challenging, but there are things that evaluators can do to mitigate such negative stakeholder attitudes. An initial step is simply being aware of the range of biases and stereotypes that stakeholders may possess, especially those that are held by stakeholders who have not experienced an evaluation before or who have had a negative experience with evaluation. Another step is acknowledging the perceived validity of the stakeholder's perspective, communicating with the stakeholder about their perspective, honoring their view, and offering alternative perspectives to challenge any negative stereotypes that exist. That is, perspective taking and communication are key for evaluators seeking to anticipate and address stakeholder stereotypes about evaluation.

Evaluator education programs, courses, and professional development experiences are opportunities for developing communication strategies to prepare practitioners to address stakeholder biases about evaluation (Gullickson, King, LaVelle, \& Clinton, 2019; King \& Stevahn, 2013; LaVelle, 2018, 2019; LaVelle \& 
Donaldson, 2010). While many evaluation courses include a subsection on communication (LaVelle, 2014), it is not immediately clear if the focus is on communicating about evaluation processes and techniques (e.g., Russ-Eft \& Preskill, 2009), results (e.g., Torres, Preskill, \& Piontek, 2005), the knowledge base of evaluation itself (e.g., Mark, 2008), evaluation theory (e.g., Alkin, 2012), or other topics. However, given that communication is an integral skill for practice and plays a prominent role in the Competencies for Canadian Evaluators (Canadian Evaluation Society, 2010), as well as in other competency taxonomies across the world, there is a gap in addressing other aspects of communication not currently covered in evaluation courses.

Language and word choice in evaluation are teachable skills that people can learn through standard pedagogical strategies. In their paper on developing a pedagogy for the teaching of evaluation, LaVelle, Lovato, and Stephenson (2020) draw from Knowles's (1980) foundational work in adult education to discuss the principles of developing learning in an evaluation context. According to Knowles, learners are self-directed, draw from their lived experiences, approach the classroom ready to learn, prefer a problem-centered approach to education, and are internally motivated to engage in learning activities.

Based on these principles, I developed a two-step activity to help participants anticipate and address stakeholder stereotypes about evaluation, a process that I have fine-tuned in workshops and classrooms across the world. The exercise begins with participants reflecting on their initial impressions of the word "evaluation" and contrasting their impressions with the definitions developed by evaluation scholars. Next, the participants assume the perspective of a program stakeholder, suggesting ways of reframing evaluation-specific words to communicate the essence of evaluation practice. The exercise ends with participants working collaboratively to develop a description of evaluation that anticipates and addresses possible stakeholder stereotypes about evaluation. What follows is a brief description of the instructional activity about evaluation bias.

\section{INSTRUCTIONAL ACTIVITY PART A: UNDERSTANDING YOUR BIASES AND STEREOTYPES ABOUT EVALUATION}

The initial setup for this 60-90-minute activity is rooted in Preskill and RussEft's $(2005,2016)$ images and purposes of evaluation activity. This beginning exercise is reflective and intended to enable participants to recognize their own biases and stereotypes about evaluation before they engage in the critical reflection and perspective taking necessary to challenge their own stereotypes. In brief:

1. Participants are asked to think about the first thing they think about when they hear about evaluation. They can draw or write something, it can be technical or emotional, or it can be in any form they are comfortable in sharing with others. There are no right or wrong answers. 
2. Participants then form small groups to share their thoughts and reflect on the emotions that the word "evaluation" elicited for them. This reflective practice takes about 10 minutes, after which participants are asked to report on what they heard and experienced in their groups (Table 1). I write the words and images on flipchart paper or a whiteboard and repeat the words and emotions back to the participants to check for accuracy.

3. I then lead a very short mini-lecture about biases and stereotypes, and provide background on how attitudes normally develop among people.

4. Finally, I contrast participants' words and images with several formal descriptions of evaluation to look for overlap and points of disagreement. I also ask them to respond to the description, recognizing that formal descriptions are often filled with jargon that might be distracting.

Instructors using this exercise will likely hear stories that range from positive to very negative. For example, a participant who described evaluation as "useless" had experienced evaluation only as an end-of-semester teacher evaluation survey and did not believe that the information was ever used formatively by the teacher or administration. The instructor must be prepared to listen to all experiences and help participants understand where their perceptions come from. I eventually draw together general themes from the discussion before transitioning into a discussion of more formal definitions of evaluation. Contrasting several definitions provides participants with a sense of the potential of evaluation as a practice and an understanding of the range of contexts and programs that might benefit

Table 1. Sample images and words associated with evaluation

\begin{tabular}{ll}
\hline Image(s) & Word(s) \\
\hline - Calculator & - Survey \\
- Spreadsheet & - Interview \\
- Math formula & - Spreadsheet \\
- Clipboard & - Test \\
- Pound sign (\#) & - Flowchart \\
- People sitting in a group & - Useless \\
- Logic model & Expensive \\
- Person with anxiety sweat & - Statistics \\
- Frown face & - Report \\
- Check mark & End-of-semester survey \\
- Dollar sign $(\$)$ & Exam \\
& - Unscientific \\
& - Learning \\
& - Occountability \\
\hline
\end{tabular}


from such a formal practice. After reading the formal descriptions, I revisit the words and pictures that the participants initially developed. The participants then discuss the formal descriptions of evaluation and contrast them with the images of evaluation they created.

\section{INSTRUCTIONAL ACTIVITY PART B: CHALLENGING STEREOTYPES ABOUT EVALUATION}

This 30-45-minute activity is intended to generate reflective practice to enable participants both to recognize their own biases about evaluation and to anticipate them in others, so that they can respectfully anticipate and address stakeholder views. In brief:

1. I begin by reminding participants that biases and stereotypes are attitudes and cognitive shortcuts for making sense of the world; they are neither good nor bad in and of themselves.

2. I then ask participants to imagine themselves as a program stakeholder. I provide vivid description about the organization, program participants, and other stakeholders.

3. I suggest to participants that the word "evaluation" could generate a physiological stress response in some people.

4. I remind participants that stakeholders might not have had a significantly different experience with evaluation than they themselves might have had at the beginning of this activity. I make the point that it is the evaluator's responsibility to challenge the stakeholder's stereotypes.

5. I ask participants how they might reframe the formal and informal descriptions of evaluation to anticipate and address possible stakeholder stereotypes of evaluation (for illustrative examples, see Tables $1 \& 2$ ).

While participants are very thoughtful in developing language to help address possible stakeholder biases, they do need guidance in framing their ideas, for example, making a distinction between evaluating a program and evaluating staff members or normalizing the process of evaluation as a practice intended to address key program questions related to program improvement. Still other participants focus on the flowchart/logic model as a tool for understanding the program, with reflections on how they might communicate its value to stakeholders.

Lastly, I lead the participants in a consensus-building activity where they develop a description of evaluation that anticipates and addresses stakeholder stereotypes about evaluation. While the outcome varies, there is consistent agreement on several main points:

- Evaluation is a systematic process; an experienced evaluator will make the process explicit from the beginning. 
Table 2. Sample biases and stereotypes of evaluation contrasted with reframing language

\begin{tabular}{|c|c|}
\hline Bias & Phrases to challenge bias \\
\hline \multirow[t]{4}{*}{ Anxiety and fear } & Anxiety is a normal and part of learning. \\
\hline & Most people fear negative evaluation. \\
\hline & $\begin{array}{l}\text { People might feel this if they think that they, rather than their } \\
\text { program, are being evaluated. }\end{array}$ \\
\hline & $\begin{array}{l}\text { It's easier to learn what works early and make small adjustments } \\
\text { than to wait until the end. }\end{array}$ \\
\hline $\begin{array}{l}\text { Math formulae } \\
\text { and statistics }\end{array}$ & $\begin{array}{l}\text { Math and statistics are a tool used in service of evaluation, not } \\
\text { an evaluation itself. }\end{array}$ \\
\hline Survey & $\begin{array}{l}\text { Surveys are an inquiry tool used in service of evaluation, not an } \\
\text { evaluation itself. }\end{array}$ \\
\hline \multirow[t]{4}{*}{ Expensive (\$) } & $\begin{array}{l}\text { Evaluations can be expensive, but the most expensive ones are } \\
\text { very complex. }\end{array}$ \\
\hline & $\begin{array}{l}\text { The better evaluations are directly aligned with stakeholder } \\
\text { questions, and those drive the price. }\end{array}$ \\
\hline & $\begin{array}{l}\text { Unintended negative outcomes can cost a lot more and can } \\
\text { hurt participants. }\end{array}$ \\
\hline & You don't have to evaluate everything all at once. \\
\hline Spreadsheet & $\begin{array}{l}\text { A spreadsheet is a data-management tool we use in service of } \\
\text { an evaluation, not an evaluation itself. }\end{array}$ \\
\hline \multirow[t]{3}{*}{ Report } & Reports are a form of communication. \\
\hline & Reporting strategies should be aligned with stakeholder needs. \\
\hline & $\begin{array}{l}\text { There are many ways of communicating that might or might not } \\
\text { include a report. }\end{array}$ \\
\hline \multirow[t]{4}{*}{ Useless } & Most evaluators believe their work should be used. \\
\hline & Use should be aligned with stakeholder needs. \\
\hline & Evaluation can be a tool for learning. \\
\hline & How do you hope the evaluation will be helpful to you? \\
\hline \multirow[t]{3}{*}{ Learning } & $\begin{array}{l}\text { Many evaluators believe that learning is an important part of } \\
\text { their work. }\end{array}$ \\
\hline & There are different types of learning. \\
\hline & What kinds of things would you like to learn about? \\
\hline \multirow[t]{3}{*}{ Flowchart } & Flowcharts are tools we use to try to understand the program. \\
\hline & $\begin{array}{l}\text { We use flowcharts to help broker conversations between } \\
\text { stakeholders. }\end{array}$ \\
\hline & Flowcharts are a story about how program participants change. \\
\hline \multirow[t]{3}{*}{ Unscientific } & Good evaluation is systematic and purposeful. \\
\hline & $\begin{array}{l}\text { Evaluation draws its design from stakeholder questions rather than } \\
\text { privileging a particular data-collection strategy or technique. }\end{array}$ \\
\hline & $\begin{array}{l}\text { "Science" is about creating generalizable knowledge, not about } \\
\text { understanding if a particular program works in a particular } \\
\text { context. }\end{array}$ \\
\hline Outsider(s) & $\begin{array}{l}\text { Internal and external evaluators bring different advantages, } \\
\text { but most will try to look at your program through a critical- } \\
\text { friend lens. }\end{array}$ \\
\hline
\end{tabular}


- Evaluation involves the inclusion of a range of stakeholders; an experienced evaluator will intentionally involve as many stakeholders as feasible for the purpose and scope of the evaluation.

- Evaluation may be used for a number of purposes; an experienced evaluator will be explicit about how an evaluation can be used as well as misused.

- Evaluation can involve a number of data-collection tools to develop and understand credible evidence; an experienced evaluator will help stakeholders weigh their options when it comes to deciding on data-collection and analysis strategies.

- Evaluation involves collective learning and understanding; an experienced evaluator will intentionally build in learning as appropriate for the stakeholders.

- Evaluation is a tangible demonstration that the stakeholder(s) care so much about their project that they are willing to take a hard look at it and see what is working and what is not; an experienced evaluator will help make the process meaningful, insightful, and practical.

- Evaluators use ethical and practical codes of conduct, such as those developed by the Canadian Evaluation Society, the American Evaluation Association, and other professional associations; an experienced evaluator will provide these documents for stakeholders.

\section{REFLECTION}

While evaluation practitioners and scholars have long recognized the need for strong communication skills during an evaluation (King \& Stevahn, 2013), relatively few tools are currently available for building evaluators' communicative capacity. The tools that are commercially available (e.g., Preskill \& Russ-Eft, $2005,2016)$ tend to be focused on the development of evaluators, with less focus on how to prepare or assist evaluators in reflective practice and perspective taking. That is, much of what has been written about communication is from the evaluator's perspective, with little written about understanding evaluation and potential evaluation biases about evaluation from the perspective of stakeholders. This is a significant omission. Words carry tremendous power, and unless they are selected and used carefully, they may unwittingly reinforce existing stakeholder biases.

To address these communication shortcomings in stakeholder biases, I blended techniques described in Preskill and Russ-Eft's $(2005,2016)$ work with the psychological foundations described in Donaldson et al. (2002) to create something to uniquely address this gap. While I think the results are effective, they do require a level of vulnerability and discomfort on the part of both the instructor and the participants, none of which is without struggle. As the participants describe their biases and stereotypes, I remind myself that their perspectives come from their experiences, real or perceived. This reflective exercise, however, enables 
participants to reframe their perspectives in a larger context, suggesting perhaps that there might be more to learn about evaluation than their prior experiences would suggest. Moreover, consistent with some of my earlier work on undergraduate college students (LaVelle, 2011), the majority of participants held views about evaluation that were top-down and reductionist, partial, and not based on its formal processes and techniques.

Feedback on my workshops and courses illustrates an additional benefit: They allow participants to see an educator who is comfortable with the boundaries of evaluation and is willing to acknowledge and accept critiques of the field without taking them personally. I occasionally hear from previous participants that their experience with these activities seemed to give them "permission" to explore their perspectives and that using the techniques in their practice has helped them more fully communicate with their stakeholders. These experiences with attitudes, biases, and stereotypes can help round out the participants' education and reflective learning and enable them to more fully appreciate the role of stakeholders in evaluation.

A key to the success of this activity, however, is reflection on themes and ideas. I refer to these biases and stereotypes-and the corresponding phrases to challenge the biases-whenever I introduce new concepts in the course or workshop. This repetition serves to remind participants of where they started from and that their stakeholders probably have not had the benefit of formal education in evaluation. By inviting the participants to join me in reframing the conversation about evaluation, I hope to humanize the process of evaluation (LaVelle, in press) and thus to provide participants with a strong foundation from which to develop high-quality, ethical work. After all, little is more foundational for building an evaluative relationship than listening, communicating, reflecting, and eventually having a stakeholder look at the evaluator and say five very important words: $I$ think you understand me.

\section{REFERENCES}

Alkin, M. C. (Ed.) (2012). Evaluation roots: A wider perspective of theorists' views and influences. Thousand Oaks, CA: Sage.

Canadian Evaluation Society (CES). (2010). Competencies for Canadian evaluators. Retrieved from http://www.eval.org

Donaldson, S. I., Gooler, L. E., \& Scriven, M. (2002). Strategies for managing evaluation anxiety: Toward a psychology of program evaluation. American Journal of Evaluation, 23(3), 261-273. https://doi.org/10.1177/109821400202300303

Guillickson, A. M., King, J. A., LaVelle, J. M., \& Clinton, J. M. (2019). The current state of educating evaluators: A situation analysis and call to action. Evaluation and Program Planning, 75, 20-30. https://doi.org/10.1016/j.evalprogplan.2019.02.012. Medline:31015094

King, J. A., \& Stevahn, L. (2013). Interactive evaluation practice: Mastering the interpersonal dynamics of program evaluation. Thousand Oaks, CA: Sage. 
Knowles, M. S. (1980). The modern practice of adult education: From pedagogy to andragogy. Englewood Cliffs, NJ: Cambridge Adult Education.

Lane, N., \& Crane, A. (2002). Revisiting gender role stereotyping in the sales profession. Journal of Business Ethics, 40(2), 121-132. https://doi.org/10.1023/a:1020343504126

LaVelle, J. M. (2011). Planning for evaluation's future: Undergraduate students' interest in program evaluation. American Journal of Evaluation, 32(3), 362-375. https://doi. org $/ 10.1177 / 1098214011398953$

LaVelle, J. M. (2014). An analysis of evaluation education programs and evaluator skills across the world [Doctoral dissertation]. Claremont Graduate University, Claremont, CA.

LaVelle, J. M. (2018). 2018 directory of evaluator education programs in the United States. University of Minnesota Libraries Publishing. Retrieved from https://conservancy. umn.edu/handle/11299/200790

LaVelle, J. M. (2019). Educating evaluators 1976-2017: An expanded analysis of universitybased evaluation education programs. American Journal of Evaluation. Advance online publication. https://doi.org/10.1177/1098214019860914

LaVelle, J. M. (in press, 2020). Using a program evaluation course to foster service and humanize students, faculty, and community partners. In E. Sengupta, P. Blessinger, and M. Makhanya (Eds.), International perspectives on integrating community service into the curriculum: Humanizing higher education. Innovations in Higher Education Teaching and Learning, V. (pp. 129-146). Bingley, England: Emerald Group Publishing.

LaVelle, J. M., \& Donaldson, S. I. (2010). University-based evaluation training programs in the United States 1980-2008: An empirical examination. American Journal of Evaluation, 31(1), 9-23. https://doi.org/10.1177/1098214009356022

LaVelle, J. M., Lovato, C., \& Stephenson, C. L. (2020). Towards a pedagogy for the teaching of evaluation. Evaluation and Program Planning. Advance online publication. https:// doi.org/10.1016/j.evalprogplan.2020.101786

Mark, M. (2008). Building a better evidence base for evaluation theory: Beyond general calls to a framework of types of research on evaluation. In N. L. Smith \& P. Brandon (Eds.), Fundamental issues in evaluation (pp. 111-134). New York, NY: The Guilford Press.

Mathison, S. (2005a). Attitudes. In S. Mathison (Ed.), Encyclopedia of evaluation (p. 23). Thousand Oaks, CA: Sage.

Mathison, S. (2005b). Bias. In S. Mathison (Ed.), Encyclopedia of evaluation (p. 33). Thousand Oaks, CA: Sage.

Preskill, H., \& Russ-Eft, D. (2005). Building evaluation capacity: 72 activities for teaching and training. Thousand Oaks, CA: Sage.

Preskill, H., \& Russ-Eft, D. (2016). Building evaluation capacity: Activities for teaching and training (2nd ed.). Thousand Oaks, CA: Sage.

Russ-Eft, D., \& Preskill, H. (2009). Evaluation in organizations a systematic approach: A systematic approach to enhancing learning, performance, and change. New York, NY: Basic Books.

Scott, B. (2000). Consulting on the inside: An internal consultant's guide to living and working inside organizations. Alexandria, VA: ASTD Press. 
Torres, R. T., Preskill, H., \& Piontek, M. E. (2005). Evaluation strategies for communicating and reporting: Enhancing learning in organizations (2nd ed.). Thousand Oaks, CA: Sage.

Triandis, H. C. (1995). A theoretical framework for the study of diversity. In M. Chemers, S. Oskamp, \& M. A. Costanzo (Eds.), Diversity in organizations: New perspectives for a changing workplace (pp. 11-36). Thousand Oaks, CA: Sage.

\section{AUTHOR INFORMATION}

John LaVelle is an assistant professor in Evaluation Studies at the University of Minnesota. His research examines how universities prepare evaluators for applied work, and he has written on the intersection of job markets and university programs, techniques for recruiting evaluators, evaluator competencies, the psychology of evaluators, and the ways in which evaluators can use social science theory to inform their practice. He was awarded the American Evaluation Association's Marcia Guttentag Award in 2019. 